\title{
The Role of Lactic Acid Bacteria in Milk Fermentation
}

\author{
Yantyati Widyastuti ${ }^{1}$, Rohmatussolihat ${ }^{1}$, Andi Febrisiantosa ${ }^{2}$ \\ ${ }^{1}$ Research Center for Biotechnology, Indonesian Institute of Sciences, Cibinong, Indonesia; ${ }^{2}$ Technical Implementation Unit for \\ Development of Chemical Engineering Processes, Indonesian Institute of Sciences, Yogyakarta, Indonesia. \\ Email: yantyati.widyastuti@lipi.go.id
}

Received December $3^{\text {rd }}$, 2013; revised January $3^{\text {rd }}$, 2014; accepted January $10^{\text {th }}, 2014$

Copyright (C) 2014 Yantyati Widyastuti et al. This is an open access article distributed under the Creative Commons Attribution License, which permits unrestricted use, distribution, and reproduction in any medium, provided the original work is properly cited. In accordance of the Creative Commons Attribution License all Copyrights @ 2014 are reserved for SCIRP and the owner of the intellectual property Yantyati Widyastuti et al. All Copyright (C) 2014 are guarded by law and by SCIRP as a guardian.

\begin{abstract}
Species of lactic acid bacteria (LAB) represent as potential microorganisms and have been widely applied in food fermentation worldwide. Milk fermentation process has been relied on the activity of LAB, where transformation of milk to good quality of fermented milk products made possible. The presence of LAB in milk fermentation can be either as spontaneous or inoculated starter cultures. Both of them are promising cultures to be explored in fermented milk manufacture. LAB have a role in milk fermentation to produce acid which is important as preservative agents and generating flavour of the products. They also produce exopolysaccharides which are essential as texture formation. Considering the existing reports on several health-promoting properties as well as their generally recognized as safe (GRAS) status of LAB, they can be widely used in the developing of new fermented milk products.
\end{abstract}

\section{KEYWORDS}

\section{Lactic Acid Bacteria; Milk Fermentation; Preservative; Flavour; Health}

\section{Introduction}

Species of lactic acid bacteria (LAB) belong to numerous genus under the family of Lactobacillaceae. They represent as potential microorganisms and have been widely applied in food fermentation worldwide due to their well known status as generally recognized as safe (GRAS) microorganisms. They are also recognised for their fermentative ability and thus enhancing food safety, improving organoleptic attributes, enriching nutrients and increasing health benefits [1-4]. Fermentation is generally considered as a safe and acceptable preservation technology of food and fermentation using LAB can be categorized into two groups based on the raw material used, non-dairy and dairy fermentation. Milk from different mammalian animals can be used in dairy fermentation to produce several products. Milk of cow followed by milk of goat and sheep are the most widely used raw materials to produce particular economic value fermented milk products worldwide. Due to the characteristics of milk that is highly perishable, the main purpose of milk fermentation using $\mathrm{LAB}$ is to prolong its shelf-life as well as to preserve the nutritious component of milk. It is also recognised that fermentation of milk using LAB will undoubtedly produce good quality of products with highly appreciated organoleptic attributes. Recently, there is a growing interest to develop a variety of fermented milk products for other beneficial purposes, particularly for health purposes and preventing of toxins produced by foodborne pathogens and spoilage bacteria that enter human body $[1,2,5,6]$. The beneficial effects of fermented milk products are produced by a variety of bioactive compounds of LAB [7].

Lactic acid bacteria represent as the most extensively studied microorganisms for milk fermentation [8-10]. The presence of LAB in milk fermentation can be either as spontaneous or inoculated starter cultures. Milk itself is known as one of the natural habitats of LAB [11,12]. Although under spontaneous fermentations the growth of LAB can not be predicted or controlled, but this procedure has been practised and carried out traditionally for years. A procedure called as backslopping is often used. There are some examples of fermented milk by LAB produced under this procedure such as those of artisanal cheese 
klila [13], kumis [14], iben [15] and kurut [16]. In general, the technology of milk fermentation is relatively simple and cost-effective. On the other hand, standardized fermented milk products are produced and manufactured in large-scale production under controlled conditions and become an important industrial application of LAB as starter cultures. There are some important features of LAB starters in fermented milk products. A single potential starter culture will dominate and reduce the diversity of microorganisms in fermented milk products compare to that of products under natural fermentation. In this review we focus on the potential role of LAB in milk fermentation based on their properties that support the development of fermented milk products.

\section{Properties of Lactic Acid Bacteria}

Milk fermentation process has been relied on the activity of LAB, which play a crucial role in converting milk as raw material to fermented milk products. In milk fermentation industry, various industrial strains of LAB are used as starter cultures. Starter cultures of LAB were obtained from a sequence activities and passed a process of isolation, selection and confirmation. Several behaviour as the characteristics of each individual selected strains of LAB has been established and used in the production of fermented milk products industrially. The most important properties of LAB are their ability to acidify milk [17] and to generate flavour and texture, by converting milk protein due to their proteolytic activities $[7,18]$. The mild acid taste and pleasant fresh, are characteristics of fermented milk products such as yoghurt and cheese.

\subsection{Preservative Property of Lactic Acid Bacteria}

Milk and fermented milk products are favorable substrates for the growth of microorganisms that may bring to spoilage condition. The most well known characteristics of $\mathrm{LAB}$ related to preservative property is their ability to produce acid, which in turn exhibit antimicrobial activity. Acidification of the milk protects the milk against spoilage microorganisms and proliferation of pathogens. LAB also release antimicrobial metabolites so called bacteriocins [19]. Both acids and bacteriocins are great potential to be used in food preservation, which are considered as safe natural preservatives.

\subsubsection{Acid Production}

Organic acids is the end product of carbohydrate metabolism produced by BAL. Homofermentative species of LAB convert sugars in milk mostly into lactic acid, whereas the heterofermentative species convert lactose into lactic acid, acetic acid, ethanol and $\mathrm{CO}_{2}$. Production of lactic acid by LAB is strain dependend. The newly identified Lactobacillus paracasei subsp. paracasei CHB2121 was reported to produce high concentrations of L (+)-lactic acid efficiently. It produced $192 \mathrm{~g} / \mathrm{L}$ lactic acid from medium containing $200 \mathrm{~g} / \mathrm{L}$ of glucose, with $3.99 \mathrm{~g} /(\mathrm{L} . \mathrm{h})$ productivity, and $0.96 \mathrm{~g} / \mathrm{g}$ yield. In addition, the optical purity of the produced lactic acid was estimated to be $96.6 \% \mathrm{~L}(+)$-lactic acid. This strain may be suitable for use in the industrial production of lactic acid [20]. A study using 10 strains of Lactobacillus showed that organic acid production was considerably influenced by media used. Three different media including skimmed milk, de Mann Rogosa Sharpe (MRS) broth and Jerusalem artichoke were used. The highest acidity was obtained in MRS broth and the weakest acidification was found in skimmed milk. Lactobacillus casei Shirota produced the highest and Lactobacillus rhamnosus VT1 the lowest amount of substances being estimated as titratable acidity. The study pointed at the dissimilarity of organic acid production of Lactobacillus strains [21]. Two Lactococcus lactis strains were studied for their ability to repress the growth of bacterial pathogens. The study showed that L. lactis subsp. lactis biovar. diacetylactis strongly inhibits the pathogenic E. coli and Salmonella enteritidis strains tested. The main inhibitory effect seemed to be associated with fast acid production which resulted in rapid $\mathrm{pH}$ reduction. Given these good attributes of $L$. lactis subsp. lactis biovar. diacetylactis, it can be recommended for use as a starter culture, preferably as a freeze-dried culture, to prepare cultured milk similar to naturally fermented milk [22].

In a yoghurt preservation period experiment and mould-proof accelerated testing at $4{ }^{\circ} \mathrm{C}$, addition of $2 \%$ $(\mathrm{v} / \mathrm{v})$ Lactobacillus casei AST18 in yogurt completely inhibited the growth of Penicillium sp., which was used as indicator fungi. L. casei AST18 produced lactic acid and cyclo-(Leu-Pro) as antifungal compounds. The addition of $L$. casei AST18 improved the quantity of Lactobacillus, but the number of Streptococcus lactis in 2\% AST18-added yoghurt decreased by $1.0 \mathrm{Log}(\mathrm{cfu} / \mathrm{mL})$ compared with that in the blank group. Direct use of antifungal strains as protective cultures presents important application value to the food industry [23]. LAB from raw milk of cow, goat and ewe are detected to have antifungal activity against 4 spoilage fungi, Penicillium expansum, Mucor plumbeus, Kluyveromyces lactis and Pichia anomala. Raw milk of cow and goat can be considered as reservoir of antifungal LAB. The most active colonies with antifungal activity belonged to Lactobacillus spp. It is suggested that their apparent specialization may be linked to organic acids and/or ethanol produced, and the tested fungi are sensitive to those molecules. Acetic acid produced by heterofermentative Lactobacilli certainly played a role in antifungal activity [11]. 


\subsubsection{Bacteriocins Production}

Bacteriocins are substances of protein structure, either proteins or polypeptides, that possessing antimicrobial activities and produced during the primary phase of bacterial growth. Generally bacteriocins only active against closely related bacterial species. Most of LAB bacteriocins are small $(<10 \mathrm{kDa})$ cationic, heat-stable, amphiphilic and membrane permeabilizing peptides. Bacteriocins of LAB can be divided into 3 classes, 1) lantibiotics, small $(<5 \mathrm{kDa})$ heat stable of peptide substances that contain the characteristic polycyclic thioether amino acids lanthionine or methyllanthionine, as well as the unsaturated amino acids dehydroalanine and 2-aminoisobutyric acid; 2) non-lantibiotics, small ( $<10 \mathrm{kDa}$ ) relatively heat stable, non-lanthionine containing membrane active peptides; and 3) bacteriocins, heat labile proteins which are in general of large molecular weight (>30 kDa) [19]. Bacteriocins can be used as partially purified or purified concentrates and supplemented to food products, although he application of bacteriocins require specific approval as food preservatives.

Among the bacteriocins produced by LAB, nisin produced by Lactococcus lactis spp., is the only bacteriocin that has been officially employed in the food industry and its use has been approved worldwide [19,24, 25]. Bacteriocins produced by wild L. lactis strains isolated from traditional starter free-cheese made from raw milk were reported as nisin $\mathrm{A}$, nisin $\mathrm{Z}$ and lactoccocin 972 [26]. L. lactis W8 produced nisin concomitantly when used to produce dahi, a traditional Indian fermented milk. Dahi prepared using L. lactis W8 showed inhibitory against L. monocytogenes ATCC 19111, Salmonella typhimurium ATCC 23565, Enterobacter aerogenes ATCC 13048 and Vibrio cholerae, however there was no inhibitory activity when cell-free supernatant of heat-treated dahi was used. L. lactis W8 appeared as a potent starter culture for production of fermented milk products of safe quality. Milk fermented with L. lactis W8 can be used as a rich source of nisin for commercial purposes [27]. Pediocin PA-1 produced by Pediococcus acidilactici is an equally promising biopreservative in foods as nisin. However, its indusrial scale production has not been taken up yet due to lack of a comparable scale of production. To improve pediocin production heterologous systems have been studied which have used a variety of promoters for enhanced expression, secretory proteins for fusion and peptide tags to facilitate purification. Pediocin is also an attractive antimicrobial agent against many pathogenic bacteria and hence has pharmaceutic application [28].

\subsection{Flavor Formation}

There are variety of fermented milk products available in the market from different parts of the world. Variation may due to the different technology applied and strains of LAB used. Cheese is among fermented milk products with high variety and may be classified based on different criteria that include the contribution of LAB strains in the ripening process. Starter cultures of LAB are responsible for the formation of cheese flavor. Several LAB are widely used and their role can be divided into starters, and non-starters, including adjunct, cultures. Main role of starter cultures is to produce acid during manufacture and also contribute to the ripening process. Non-starter cultures do not responsible to the production of acid, but they contribute more during ripening process. Flavor formation and the characteristics flavor of individual cheese varieties are develop during ripening process by both starter and non-starter LAB. All LAB are active sinergistically to produce specific flavor of the cheese products (Table 1). Several steps in cheese flavor development by LAB including metabolism of lactose, lactate and citrate; lypolysis that liberate free fatty acids and proteolysis where degradation of casein followed by amino acid catabolism occured [30]. Effort to improve the quality of cheese by producing cheese with specific flavor has been of increasing interest and researches focusing on the use of potential starters derived new and powerful technology have been widely carried out [18,31-33].

The most common LAB cultures used in yoghurt manufacture is Streptococcus thermophilus and Lactobacillus bulgaricus. They, in association and synegistically, produce volatile metabolites that determine the flavour of yoghurt. The mutual benefit between them occured by releasing the amino acids from the milk as well as organic acids and therefore they produced more lactic acid and aromatic compounds [34]. Flavour of yoghurt are supported by various compounds, in which lactic acid represents as the major contributor, and other aroma compounds (Figure 1).

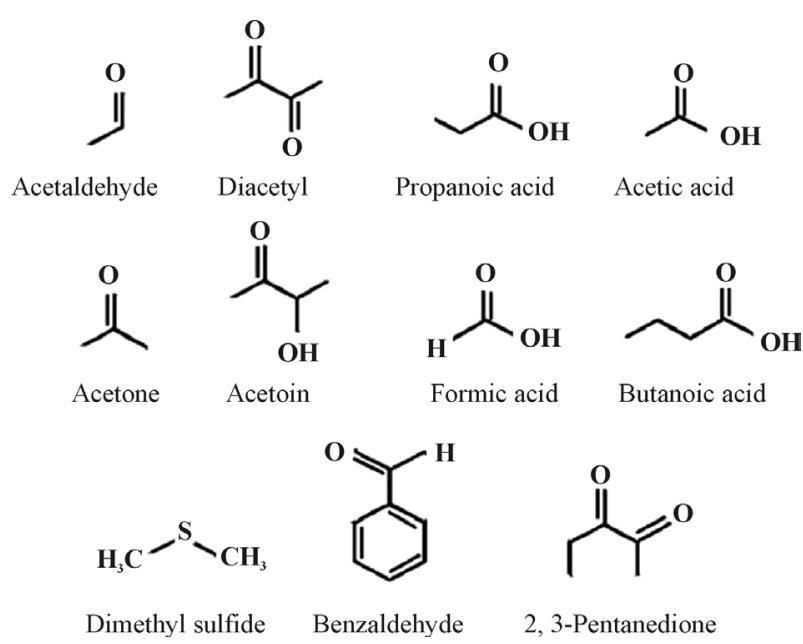

Figure 1. Major aroma compounds in yoghurt [34]. 
Table 1. Major aroma compounds in cheese derived from amino acids [29].

\begin{tabular}{|c|c|c|c|c|}
\hline Amino acids & Aldehydes & Alcohols & Carboxylic acids & Thyol/divers \\
\hline Leucine & 3-Methylbutanal or Isovaleraldehyde & 3-Methylbutanol & 3-Methylbutanoic acid or isovaleric acid & \\
\hline Isoleucine & 2-Methylbutanal & 2-Methylbutanol & 2-Methylbutanoic acid & \\
\hline Valine & 2-Methylpropanal or isobutyraldehyde & 2-Methylpropanol & 2-Methylpropanoic acid or isobutyric acid & \\
\hline Phenylalanine & Phenylacetaldehyde, benzaldehyde (-2C) & Phenylethanol & Phenylacetic acid & \\
\hline Tyrosine & OH-Phenylacetaldehyde, OH-benzaldehyde (-2C) & OH-Phenylethanol & OH-Phenylacetic acid & p-cresol, phenol \\
\hline Tryptophane & Indol-3-acetaldehyde, indol-3-aldehyde & Tryptophol & Indol-3-acetic acid & Skatole, indole \\
\hline Methionine & 3-Methylthiopropanal, or methional & 3-Methylthiopropanol & 3-Methylthiopropionic acid & Methanethiol \\
\hline
\end{tabular}

\subsubsection{Starter Cultures of Lactic Acid Bacteria for Cheese Production}

Starter cultures of LAB can be either mesophilic from the genera of Lactococcus and Leuconostoc or thermophilic from the genera of Streptococcus and Lactobacillus [35]. Among species, Lactococcus lactis [36,37], Streptococcus thermophilus [30,38] and Lactobacillus helveticus [36-42] are intensively studied. L. helveticus is specialized of milk species and belong to the member of dairy niche species $[43,44]$ Several cheese products are based on L. helveticus as starter (Table 2). It is also known that $L$. helveticus have significant role in production of specific flavor compounds in Italian cheese types [46,47] and debittering of cheese $[48,49]$.

\subsubsection{Non Starter Cultures of Lactic Acid Bacteria}

Non starter LAB play important role in cheese ripening. Non starter LAB released enzymes that participate in the basic role of the transformation of curd in cheese. Since the population of non starter LAB is uncontrol, it is suggested that selection of strains to be developed to maintain a certain cheese flavour [50]. In traditional cheeses, their flavor intensity also from the non-starter LAB [51].

\subsection{Texture Development}

Youghurt is a special fermented milk product which have a texture of soft and thicker compare to that of its raw material, the milk. The mild acid with pleasant fresh taste supported characteristics of yoghurt as an extraordinary fermented milk product. The texture of yoghurt is supported by production of exopolysaccharides (EPS), as viscosifying agent, produced by LAB. It is also suggested that is contributed by coagulation, as a result of neutralisation of the negative charges on the milk proteins, as another effect of acid produced by LAB. EPS is produced by some of LAB, depending on the strain [52].

\subsection{Health-promoting Property of Lactic Acid Bacteria}

The high demand of fermented milk products is due to
Table 2. The use of $L$. helveticus as cheese starter [45].

\begin{tabular}{ccc}
\hline No & Cheese product & Type of starter \\
\hline 1. & Asiago & Natural whey and milk culture \\
2. & Canestrato Pugliese & Natural whey culture \\
3. & Emmental & Commercial culture \\
4. & Grana Padano & Natural whey culture \\
5. & Gruyère & Commercial culture \\
6. & Montasio & Natural whey culture \\
7. & Mozzarella & Natural culture and commercial culture \\
8. & Parmigiano Reggiano & Natural culture \\
9. & Pecorino Romano & Natural culture in scotta \\
10. & Pecorino Sardo & Natural whey and milk culture \\
11. & Pecorino Siciliano & Natural whey culture \\
12. & Provolone Italiano & Natural whey culture \\
13. & Sbrinz & Commercial culture \\
14. & Taleggio & Commercial culture \\
\hline & &
\end{tabular}

the health property generating from consumption of fermented milk products. Bioactive peptides produced from hydrolysis of casein in milk generated by L. helveticus have been reviewed and showed effect of antihypertensive, immunomodulatory activity, anti-cancer and calcium binding ability. L. helveticus is known as one of LAB which has efficient proteolytic system [7]. Fermented milk products are reported to contribute to human health through several mechanisms [2] LAB are in the first rank of listed organisms as species used in probiotic preparation. LAB, in general, showed to possess most of the requirements for strains to be called as probiotics. [53-57]. Fermented milk products with their beneficial effect are presented in Table 3.

\section{Concluding Remarks}

LAB are widely applied to several milk products due to 
Table 3. Functional benefit of fermented milk products using lactic acid bacteria.

\begin{tabular}{|c|c|c|c|c|}
\hline Product name & Origin & Culture & Functional benefit & Reference \\
\hline Probiotic yogurt & Ontario, Canada & L. rhamnosus CAN-1 & $\begin{array}{l}\text { Nutrition and immune function for } \\
\text { people living with HIV }\end{array}$ & [58] \\
\hline $\begin{array}{l}\text { Mix ewe's and } \\
\text { goat's milk yoghurt }\end{array}$ & $\begin{array}{l}\text { Antakya-Hatay, } \\
\text { Turkey }\end{array}$ & $\begin{array}{l}\text { S. thermophilus and L. delbrueckii subsp. } \\
\text { bulgaricus (codes: CH-1 and YF-333) }\end{array}$ & High short chain free fatty acids & [59] \\
\hline $\begin{array}{l}\text { Ayran (yoghurt } \\
\text { from goat milk) }\end{array}$ & Turkey & $\begin{array}{l}\text { L. plantarum, L. brevis } \\
\text { L. paracasei subsp. paracasei, } \\
\text { L. casei subsp. pseudoplantarum }\end{array}$ & High exopolysacharide & {$[60]$} \\
\hline $\begin{array}{l}\text { Gioddu, traditional } \\
\text { fermented sheep or } \\
\text { goat milk }\end{array}$ & Sardinian, Italy & $\begin{array}{l}\text { S. thermophilus, L. lactis subsp. lactis } \\
\text { L. delbrueckii subsp. bulgaricus, } \\
\text { L. casei subsp. casei, } \\
\text { L. mesenteroides subsp. mesenteroides }\end{array}$ & Probiotic & [61] \\
\hline Tarag & Mongolia & L. helveticus, L. lactis subsp. lactis, L.casei & Probiotic & [62] \\
\hline Fermented milk & Japan & L. casei strain Shirota & $\begin{array}{l}\text { Maintenance treatment for myelopathy/tropical } \\
\text { spastic paraparesis (HAM/TSP) patients }\end{array}$ & [63] \\
\hline $\begin{array}{l}\text { Koumiss from } \\
\text { mare’s milk }\end{array}$ & Italy & L. delbrueckii subsp. bulgaricus S. thermophilus & Antiallergic & {$[64]$} \\
\hline Lben & Marocco & Spontaneously/not identified & Low fat and high calcium traditional product & [65] \\
\hline $\begin{array}{l}\text { Functional } \\
\text { fermented milk }\end{array}$ & Italy & L. lactis DIBCA2, L. plantarum PU11 & $\begin{array}{l}\text { Enriched of Angiotensin-I Converting } \\
\text { Enzyme (ACE)-inhibitory peptides and G-amino } \\
\text { butyric acid (GABA) }\end{array}$ & {$[66]$} \\
\hline Kumis & West Colombia & E. faecalis, E. faecium & ACE Inhibitor & [67] \\
\hline $\begin{array}{l}\text { Ewe milk, } \\
\text { traditional yoghurt }\end{array}$ & Iran & L. brevis & cholesterol reduction & [68] \\
\hline Maasai & Kenya & $\begin{array}{l}\text { L. plantarum, L. fermentum, } \\
\text { L. acidophillus, L. paracasei }\end{array}$ & Diarrhoea and constipation & [69] \\
\hline Suusac & Kenya & $\begin{array}{c}\text { L. curvatus, } L \text {. plantarum, } \\
\text { L. salivarius, } L \text {. raffinolactis } \\
\text { Leuconostoc mesenteroides subsp. mesenteroides. }\end{array}$ & & {$[70]$} \\
\hline
\end{tabular}

their specific properties. Both starter and non-starter are promising cultures to be explored in fermented milk manufacture. Considering the important status as GRAS microorganisms, LAB can be used widely in the developing of new fermented milk product.

\section{REFERENCES}

[1] P. S. Panesar, "Fermented Dairy Products: Starter Cultures and Potential Nutritional Benefits," Food and Nutrition Sciences, Vol. 2, No. 1, 2011, pp. 47-51. http://dx.doi.org/10.4236/fns.2011.21006

[2] R. Sharma, B. S. Sanodiya, D. Bagrodia, M. Pandey, A. Sharma and P. S. Bisen, "Efficacy and Potential of Lactic Acid Bacteria Modulating Human Health,” International Journal of Pharma and Bio Sciences, Vol. 3, No. 4, 2012, pp. 935-948.

[3] J. Steele, J. Broadbent and J. Kok, "Perspective on the Contribution of Lactic Acid Bacteria to Cheese Flavor Development," Current Opinion in Biotechnology, Vol. 24, No. 2, 2013, pp. 135-141. http://dx.doi.org/10.1016/j.copbio.2012.12.001

[4] S.-N. Liu, Y. Han and Z.-J. Zhou, "Lactic Acid Bacteria in Traditional Fermented Chinese Foods,” Food Research
International, Vol. 44, No. 3, 2011, pp. 643-651. http://dx.doi.org/10.1016/j.foodres.2010.12.034

[5] N. P. Shah, "Functional Cultures and Health Benefits," International Dairy Journal, Vol. 17, No. 11, 2007, pp. 1262-1277. http://dx.doi.org/10.1016/j.idairyj.2007.01.014

[6] A. A. Ali, "Beneficial Role of Lactic Acid Bacteria in Food Preservation and Human Health,” Research Journal of Microbiology, Vol. 5, No. 12, 2010, pp. 1213-1221. http://dx.doi.org/10.3923/jm.2010.1213.1221

[7] M. W. Griffiths and A. M. Tellez, "Lactobacillus helveticus: The Proteolytic System," Frontiers in Microbiology, Vol. 4, 2013, pp. 1-9. http://dx.doi.org/10.3389/fmicb.2013.00030

[8] N. F. Olson, "The Impact of Lactic Acid Bacteria on Cheese Flavor," FEMS Microbiology Reviews, Vol. 87, No. 1-2, 1990, pp. 131-148.

http://dx.doi.org/10.1111/j.1574-6968.1990.tb04884.x

[9] G. Urbach, "Contribution of Lactic Acid Bacteria to Flavour Compound Formation in Dairy Products," International Dairy Journal, Vol. 5, No. 8, 1995, pp. 877-903. http://dx.doi.org/10.1016/0958-6946(95)00037-2

[10] P. A. Maragkoudakis, C. Miaris, P. Rojez, N. Manalis, F. Magkanari, G. Kalantzopoulos and E. Tsakalidou, "Pro- 
duction of Traditional Greek Yoghurt Using Lactobacillus Strains with Probiotic Potential as Starter Adjuncts,” International Dairy Journal, Vol. 16, No. 1, 2006, pp. 5260. http://dx.doi.org/10.1016/j.idairyj.2004.12.013

[11] E. Delavenne, J. Mounier, F. Déniel, G. Barbier and G. Le Blay, "Biodiversity of Antifungal Lactic Acid Bacteria Isolated from Raw Milk Samples from Cow, Ewe and Goat over One-Year Period," International Journal of Food Microbiology, Vol. 155, No. 3, 2012, pp. 185-190. http://dx.doi.org/10.1016/j.ijfoodmicro.2012.02.003

[12] J. T. M. Wouters, E. H. E. Ayad, J. Hugenholtz and G. Smit, "Microbes from Raw Milk for Fermented Dairy Products,” International Dairy Journal, Vol. 12, No. 2-3, 2002, pp. 91-109. http://dx.doi.org/10.1016/S0958-6946(01)00151-0

[13] Z. Mennane, K. Khedid, A. Zinedine, M. Lagzouli, M. Ouhssine and M. Elyachioui, "Microbial Characteristics of Klila and Jben Traditionnal Moroccan Cheese from Raw Cow's Milk," World Journal of Dairy \& Food Sciences, Vol. 2, No. 1, 2007, pp. 23-27.

[14] C. Chaves-López, A. Serio, M. Martuscelli, A. Paparella, E. Osorio-Cadavid and G. Suzzi, "Microbiological Characteristics of Kumis, a Traditional Fermented Colombian Milk, with Particular Emphasis on Enterococci Population," Food Microbiology, Vol. 28, No. 5, 2011, pp. 1041-1047. http://dx.doi.org/10.1016/j.fm.2011.02.006

[15] M. Ouadghiri, M. Vancanneyt, P. Vandamme, S. Naser, D. Gevers, K. Lefebvre, J. Swings and M. Amar, "Identification of Lactic Acid Bacteria in Moroccan Raw Milk and Traditionally Fermented Skimmed Milk 'Lben', Journal of Applied Microbiology, Vol. 106, No. 2, 2008, pp. 486-495. http://dx.doi.org/10.1111/j.1365-2672.2008.04016.x

[16] Z. Sun, W. Liu, W. Gao, M. Yang, J. Zhang, L. Wu, J. Wang, B. Menghe, T. Sun and H. Zhang, "Identification and Characterization of the Dominant Lactic Acid Bacteria from Kurut: The Naturally Fermented Yak Milk in Qinghai, China,” Journal of General and Appllied Microbiology, Vol. 56, No. 1, 2010, pp. 1-10.

[17] A. Mäyrä-Mäkinen and M. Bigret, "Industrial Use and Production of Lactic Acid Bacteria,” In: S. Salminen, A. von Wright and A. Ouwehand, Eds., Lactic Acid Bacteria Microbiological and Functional Aspects, Marcel Dekker, Inc., New York, 2004, pp. 175-198.

[18] J. M. Kongo, "Lactic Acid Bacteria as Starter-Cultures for Cheese Processing: Past, Present and Future Developments," Chapter 1, 2013. http://creativecommons.org/licenses/by/3.0

[19] M. P. Zacharof and R. W. Lovitt, "Bacteriocins Produced by Lactic Acid Bacteria,” APCBEE Procedia, Vol. 2, 2012, pp. 50-56. http://dx.doi.org/10.1016/j.apcbee.2012.06.010

[20] S.-K. Moon, Y.-J. Wee and G.-W. Choi, “A Novel Lactic Acid Bacterium for the Production of High Purity LLactic Acid, Lactobacillus paracasei subsp. paracasei CHB2121," Journal of Bioscience and Bioengineering, Vol. 114, No. 2, 2012, pp. 155-159.

http://dx.doi.org/10.1016/j.jbiosc.2012.03.016

[21] Z. Zalán, J. Hudáček, J. Štětina, J. Chumchalová, A.
Halász, "Production of Organic Acids by Lactobacillus Strains in Three Different Media," European Food Research Technology, Vol. 230, No. 3, 2010, pp. 395-404. http://dx.doi.org/10.1007/s00217-009-1179-9

[22] J. Mufandaedza, B. C. Viljoen, S. B. Feresu and T. H. Gadaga, "Antimicrobial Properties of Lactic Acid Bacteria and Yeast-LAB Cultures Isolated from Traditional Fermented Milk against Pathogenic Escherichia coli and Salmonella enteritidis Strains," International Journal of Food Microbiology, Vol. 108, No. 1, 2006, pp. 147-152. http://dx.doi.org/10.1016/j.ijfoodmicro.2005.11.005

[23] H. Li, L. Liu, S. Zhang, H. Uluko, W. Cui and J. Lv, "Potential Use of Lactobacillus casei AST18 as a Bioprotective Culture in Yogurt," Food Control, Vol. 34, No. 2, 2013, pp. 675-680. http://dx.doi.org/10.1016/j.foodcont.2013.06.023

[24] E. M. Balciunas, F. A. C. Martinez, S. D. Todorov, B. D. G. de Melo Franco, A. Converti and R. P. de Souza Oliveira, "Novel Biotechnological Applications of Bacteriocins: A Review,” Food Control, Vol. 32, No. 1, 2013, pp. 134-142. http://dx.doi.org/10.1016/j.foodcont.2012.11.025

[25] S. Mitra, P. K. Chakrabartty and S. R. Biswas, "Potential Production and Preservation of Dahi by Lactococcus lactis W8 a Nisin-Producing Strain,” LWT-Food Science and Technology, Vol. 43, No. 2, 2010, pp. 337-342. http://dx.doi.org/10.1016/j.lwt.2009.08.013

[26] Á. Alegría, S. Delgado, C. Roces, B. López and B. Mayo, "Bacteriocins Produced by Wild Lactococcus lactis Strains Isolated from Traditional Starter-Free Cheeses Made of Raw Milk,” International Journal of Food Microbiology, Vol. 143, No. 1, 2010, pp. 61-66. http://dx.doi.org/10.1016/j.ijfoodmicro.2010.07.029

[27] S. Mitra, P. K. Chakrabartty and S. R. Biswas, "Potential Production and Preservation of Dahi by Lactococcus lactis W8, a Nisin-Producing Strain,” LWT-Food Science and Technology, Vol. 43, No. 2, 2010, pp. 337-342. http://dx.doi.org/10.1016/j.lwt.2009.08.013

[28] B. Kumar, P. P. Balgir, B. Kaur and N.Garg, "Cloning and Expression of Bacteriocins of Pediococcus spp.: A Review," Archives of Clinical Microbiology, Vol. 2, No. 3, 2011, p. 4.

[29] M. Yvon and L. Rijnen, "Cheese Flavour Formation by Amino Acid Catabolism,” International Dairy Journal, Vol. 11, No. 4-7, 2001, pp. 185-201. http://dx.doi.org/10.1016/S0958-6946(01)00049-8

[30] P. L. H. McSweeney and M. J. Sousa, "Biochemical Pathways for the Production of Flavour Compounds in Cheese during Ripening: A Review,” Lait, Vol. 80, No. 3, 2000, pp. 293-324. http://dx.doi.org/10.1051/lait:2000127

[31] P. Hols, F. Hancy, L. Fontaine, B. Grossiord, D. Prozzi, N. Leblond-Bourget, B. Decaris, A. Bolotin, C. Delorme, S. D. Ehrlich, E. Guédon, V. Monnet, P. Renault and M. Kleerebezem, "New Insights in the Molecular Biology and Physiology of Streptococcus thermophilus Revealed by Comparative Genomics,” FEMS Microbiology Review, Vol. 29, No. 3, 2005, pp. 435-463.

[32] J. R. Broadbent, H. Cai, R. L. Larsen, J. E. Hughes, D. L. Welker, V. G. De Carvalho, T. A. Tompkins, Y. Ardo, F. 
Vogensen, A. De Lorentiis, M. Gatti, E. Neviani and J. L. Steele, "Genetic Diversity in Proteolytic Enzymes and Amino Acid Metabolism among Lactobacillus helveticus Strains,” Journal of Dairy Science, Vol. 94, No. 9, 2011, pp. 4313-4328. http://dx.doi.org/10.3168/jds.2010-4068

[33] J. Steele, J. Broadbent and J. Kok, "Perspective on the Contribution of Lactic Acid Bacteria to Cheese Flavor Development," Current Opinion in Biotechnology, Vol. 24, No. 2, 2013, pp. 135-141. http://dx.doi.org/10.1016/j.copbio.2012.12.001

[34] W. Routray and H. N. Mishra, "Scientific and Technical Aspects of Yogurt Aroma and Taste: A Review," Comprehensive Reviews in Food Science and Food Safety, Vol. 10, No. 4, 2011, pp. 208-220. http://dx.doi.org/10.1111/j.1541-4337.2011.00151.x

[35] P. F. Fox, P. L. H. McSweeney, T. M. Cogan and T. P. Guinee, "Cheese: Chemistry, Physics and Microbiology," Elsevier, 2004.

[36] B. Dias and B. Weimer, "Conversion of Methionine to Thiols by Lactococci, Lactobacilli, and Brevibacteria," Applied and Environmental Microbiology, Vol. 64, No. 9, 1998, pp. 3320-3326.

[37] J. A. Hannon, K. N. Kilcawley, M. G. Wilkinson, C. M. Delahunty and T. P. Beresford, "Flavor Precursor Development in Cheddar Cheese Due to Lactococcal Starters and the Presence and Lysis of Lactobacillus helveticus," International Dairy Journal, Vol. 17, No. 4, 2007, pp. 316327.

[38] S. Helinck, D. L. Bars, D. Moreau and M. Yvon, “Ability of Thermophilic Lactic Acid Bacteria to Produce Aroma Compounds from Amino Acids," Applied and Environmental Microbiology, Vol. 70, No. 7, 2004, pp. 38553681.

http://dx.doi.org/10.1128/AEM.70.7.3855-3861.2004

[39] N. Klein, M. B. Maillard, A. Thierry and S. Lortal, "Conversion of Amino Acids into Aroma Compounds by CellFree Extracts of Lactobacillus helveticus," Journal of Applied Microbiology, Vol. 91, No. 3, 2001, pp. 404-411. http://dx.doi.org/10.1046/j.1365-2672.2001.01391.x

[40] O. Kenny, R. J. FitzGerald, G. O’Cuinn, T. Beresford and K. Jordan, "Autolysis of Selected Lactobacillus helveticus Adjunct Strains during Cheddar Cheese Ripening," International Dairy Journal, Vol. 16, No. 7, 2006, pp. 797-804. http://dx.doi.org/10.1016/j.idairyj.2005.07.008

[41] W. J. Lee, D. S. Banavara, J. E. Hughes, J. K. Christiansen, J. L. Steele, J. R. Broadbent and S. A. Rankin, "Role of Cystathionine $\beta$-Lyase in Catabolism of Amino Acids to Sulfur Volatiles by Genetic Variants of Lactobacillus helveticus CNRZ 32," Applied and Environmental Microbiology, Vol. 73, No. 9, 2007, pp. 3034-3039. http://dx.doi.org/10.1128/AEM.02290-06

[42] J. K. Christiansen, J. E. Hughes, D. L. Welker, B. T. Rodríguez, J. L. Steele and J. R. Broadbent, "Phenotypic and Genotypic Analysis of Amino Acid Auxotrophy in Lactobacillus helveticus CNRZ 32," Applied and Environmental Microbiology, Vol. 74, No. 2, 2008, pp. 416-423. http://dx.doi.org/10.1128/AEM.01174-07

[43] M. Callanan, P. Kaleta, J. O’Callaghan, O. O’Sullivan, K. Jordan, O. McAuliffe, A. Sangrador-Vegas, L. Slattery, G.
F. Fitgerald, T. Beresford and R. P. Ross, "Genome Sequence of Lactobacillus helveticus, an Organism Distinguished by Selective Gene Loss and Insertion Sequence Element Expansion,” Journal of Bacteriology, Vol. 190, No. 2, 2008, pp. 727-735. http://dx.doi.org/10.1128/JB.01295-07

[44] L. Slaterry, J. O. Callaghan, G. F. Fitgerald, T. Beresford and R. P. Ross, "Invited Review: Lactobacillus helveticusA Thermophilic Dairy Starter Related to Gut Bacteria," Journal of Dairy Science, Vol. 93, No. 10, 2010, pp. 44354454. http://dx.doi.org/10.3168/jds.2010-3327

[45] M. Gobbetti, M. De Angelis, R. Di Cagno and C. G. Rizzello, "The Relative Contributions of Starter Cultures and Non-Starter Bacteria to the Flavour of Cheese,” In: B. C. Weimer, Ed., Improving the Flavor of Cheese, CRC Press Boca Raton, 2007, pp. 121-156.

[46] M. Gatti, C. Lazzi, L. Rossetti, G. Mucchetti and E. Neviani, "Biodiversity in Lactobacillus helveticus Strains Present in Natural Whey Starter Used for Parmigiano Reggiano Cheese,” Journal of Applied Microbiology, Vol. 95, No. 3, 2003, pp. 463-470. http://dx.doi.org/10.1046/j.1365-2672.2003.01997.x

[47] L. Rossetti, M. E. Fornasari, M. Gatti, C. Lazzi, E. Neviani and G. Giraffa, "Grana Padano Cheese Whey Starters: Microbial Composition and Strain Distribution,” International Journal of Food Microbiology, Vol. 127, No. 1-2, 2008, pp. 168-171.

http://dx.doi.org/10.1016/j.ijfoodmicro.2008.06.005

[48] L. Fernández, T. Bhowmik and J. Steele, "Characterization of the Lactobacillus helveticus CNRZ32 pepC Gene," Applied and Environmental Microbiology, Vol. 60, No. 1, 1994, pp. 333-336.

[49] E. Soeryapranata, J. R. Powers and G. Ünlü, “Cloning and Characterization of Debittering Peptidases, PepE, PepO, PepO2, PepO3 and PepN, of Lactobacillus helveticus WSU 19,” International Dairy Journal, Vol. 17, No. 9, 2007, pp. 1096-1106.

[50] L. Settani and G. Moschetti., "Non-Starter Lactic Acid Bacteria Used to Improve Cheese Quality and Provide Health Benefits,” Food Microbiology, Vol. 27, No. 6, 2010, pp. 691-697. http://dx.doi.org/10.1016/j.fm.2010.05.023

[51] T. P. Beresford, N. A. Fitzsimons, N. L. Brennan and T. M. Cogan, "Recent Advances in Cheese Microbiology," International Dairy Journal, Vol. 11, No. 4-7, 2001, pp. 259-274. http://dx.doi.org/10.1016/S0958-6946(01)00056-5

[52] T. X. Yang, K. Y. Wu, F. Wang, X. L. Liang, Q. S. Liu, G. Li and Q. Y. Li, "Effect of Exopolysaccharides from Lactic Acid Bacteria on the Texture and Microstructure of Buffalo Yoghurt,” International Dairy Journal, Vol. 34, No. 2, 2014, pp. 252-256. http://dx.doi.org/10.1016/j.idairyj.2013.08.007

[53] J. Fioramonti, V. Theodorou and L. Bueno, "Probiotics: What Are They? What Are Their Effects on Gut Physiology?” Best Practice \& Research Clinical Gastroenterology, Vol. 17, No. 5, 2003, pp. 711-724. http://dx.doi.org/10.1016/S1521-6918(03)00075-1

[54] I. P. Kaur, K. Chopra and A. Saini, "Probiotics: Potential Pharmaceutical Applications,” European Journal of Phar- 
maceutical Sciences, Vol. 15, No. 1, 2002, pp. 1-9. http://dx.doi.org/10.1016/S0928-0987(01)00209-3

[55] T. Vasiljevic and N. P. Shah, "Probiotics-From Metchnikoff to Bioactives," International Dairy Journal, Vol. 18, No. 7, 2008, pp. 714-728. http://dx.doi.org/10.1016/j.idairyj.2008.03.004

[56] G. Giraffa, N. Chanishvili and Y. Widyastuti, "Importance of Lactobacilli in Food and Feed Biotechnology," Research in Microbiology, Vol. 161, No. 6, 2010, pp. 480487. http://dx.doi.org/10.1016/j.resmic.2010.03.001

[57] K. Singh, B. Kallali, A. Kumar and V. Thaker, "Probiotics: A Review," Asian Pacific Journal of Tropical Biomedicine, Vol. 1, No. 2, 2011, pp. S287-S290.

[58] J. Hemsworth, S. Hekmat and G. Reid., "The Development of Micronutrient Supplemented Probiotic Yogurt for People Living with HIV: Laboratory Testing and Sensory Evaluation,” Innovative Food Science and Emerging Technologies, Vol. 12, No. 1, 2011, pp. 79-84. http://dx.doi.org/10.1016/j.ifset.2010.11.004

[59] Z. Guler and A. C. Gürsoy-Balcı, "Evaluation of Volatile Compounds and Free Fatty Acids in Set Types Yogurts Made of Ewes', Goats' Milk and Their Mixture Using Two Different Commercial Starter Cultures during Refrigerated Storage,” Food Chemistry, Vol. 127, No. 3, 2011, pp. 1065-1071. http://dx.doi.org/10.1016/j.foodchem.2011.01.090

[60] F. Altay, F. Karbancioglu-Güler, C. Daskaya-Dikmen and D. Heperkan, “A Review on Traditional Turkish Fermented Non-Alcoholic Beverages: Microbiota, Fermentation Process and Quality Characteristics,” International Journal of Food Microbiology, Vol. 167, No. 1, 2013, pp. 44-56. http://dx.doi.org/10.1016/j.ijfoodmicro.2013.06.016

[61] S. Ortu, G. E. Felis, M. Marzotto, A. Deriu, P. Molicotti, L. A. Sechi, F. Dellaglio and S. Zanetti, "Identification and Functional Characterization of Lactobacillus Strains Isolated from Milk and Gioddu, a Traditional Sardinian Fermented Milk,” International Dairy Journal, Vol. 17, No. 11, 2007, pp. 1312-1320. http://dx.doi.org/10.1016/j.idairyj.2007.02.008

[62] W. Liu, Q. Bao, Jirimutu, M. Qing, Siriguleng, X. Chen, T. Sun, M. Li, J. C. Zhang, M. Bilige, T. S. Sun and H. P. Zhang, "Isolation and Identification of Lactic Acid Bacteria from Tarag in Eastern Inner Mongolia of China by 16S rRNA Sequences and DGGE Analysis,” Microbiological Research, Vol. 167, No. 2, 2012, pp. 110-115. http://dx.doi.org/10.1016/j.micres.2011.05.001

[63] T. Matsuzaki, M. Saito, K. Usuku, H. Nose, S. Izumo, K. Arimura and M. Osame, "A Prospective Uncontrolled
Trial of Fermented Milk Drink Containing Viable Lactobacillus casei Strain Shirota in the Treatment of HTLV-1 Associated Myelopathy/Tropical Spastic Paraparesis," Journal of the Neurological Sciences, Vol. 237, No. 1, 2005, pp. 75-81.

http://dx.doi.org/10.1016/j.jns.2005.05.011

[64] R. D. Cagno, A. Tamborrino, G. Gallo, C. Leone, M. De Angelis, M. Faccia, P. Amiranteb and M. Gobbettia, "Uses of Mares' Milk in Manufacture of Fermented Milks," International Dairy Journal, Vol. 14, No. 9, 2004, pp. 767-775. http://dx.doi.org/10.1016/j.idairyj.2004.02.005

[65] M. Ouadghiri, M. Vancanneyt, P. Vandamme, S. Naser, D. Gevers, K. Lefebvre, J. Swings and M. Amar, "Identification of Lactic Acid Bacteria in Moroccan Raw Milk and Traditionally Fermented Skimmed Milk 'Lben', Journal of Applied Microbiology, Vol. 106, No. 2, 2008, pp. 486-495. http://dx.doi.org/10.1111/j.1365-2672.2008.04016.x

[66] F. Nejati, C. G. Rizzello, R. Di Cagno, M. Sheikh-Zeinoddin, A. Diviccaro, F. Minervini and M. Gobbetti, "Manufacture of a Functional Fermented Milk Enriched of Angiotensin-I Converting Enzyme (ACE)-Inhibitory Peptides and g-Amino Butyric Acid (GABA)," LWT-Food Science and Technology, Vol. 51, No. 1, 2013, pp. 183-189. http://dx.doi.org/10.1016/j.lwt.2012.09.017

[67] C. Chaves-López, A. Serio, M. Martuscelli, A. Paparella, E. Osorio-Cadavid and G. Suzzi, "Microbiological Characteristics of Kumis, a Traditional Fermented Colombian Milk, with Particular Emphasis on Enterococci Population,” Food Microbiology, Vol. 28, No. 5, 2011, pp. 10411047. http://dx.doi.org/10.1016/j.fm.2011.02.006

[68] M. Iranmesh, H. Ezzatpanah and N. Mojgani, “Antibacterial Activity and Cholesterol Assimilation of Lactic Acid Bacteria Isolated from Traditional Iranian Dairy Products,” LWT-Food Science and Technology, 2013, pp. 1-5.

[69] J. M. Mathara, U. Schillinger, P. M. Kutima, S. K. Mbugua and W. H. Holzapfel, "Isolation, Identification and Characterisation of the Dominant Microorganisms of Kule Naoto: The Maasai Traditional Fermented Milk in Kenya,” International Journal of Food Microbiology, Vol. 94, No. 3, 2004, pp. 269-278. http://dx.doi.org/10.1016/j.ijfoodmicro.2004.01.008

[70] T. A. Lore, S. K. Mbugua and J. Wangoh, "Enumeration and Identification of Icroflora in Suusac, a Kenyan Traditional Fermented Camel Milk Product," LWT-Food Science and Technology, Vol. 38, No. 2, 2005, pp. 125130. http://dx.doi.org/10.1016/j.lwt.2004.05.008 